\title{
BALI JAWI \\ Menghidupkan Kembali Nilai-Nilai Luhur Manusia Jawa
}

\author{
Oleh: \\ Anter Asmorotedjo \\ Program Pascasarjana Institut Seni Indonesia Yogyakarta \\ email: anterdans.arts@gmail.com
}

\section{RINGKASAN}

Tari berjudul Bali Jawi, sebuah karya yang terinspirasi dari sebuah ritual tradisi Jawa yang sering disebut dengan sowan leluhur. Ritual tersebut sering dilakukan oleh masyarakat penganut paham spiritual Jawa atau yang sering disebut dengan kejawen. Ritual sowan leluhur dipercaya sebagai warisan para leluhur Nuswantara. Para pelaku spiritual Jawa percaya bahwa para leluhur selalu njampangi anak cucunya, maka ritual tersebut sebagai wujud bakti dan bukti memuliakan para leluhurnya. Salah satu situs yang sering dikunjungi untuk ritual tersebut adalah Watu Gilang di Kotagede yang merupakan singgasana raja peninggalan kerajaan Mataram.

Dari ritual yang dilakukan, banyak nilai-nilai luhur yang terkandung di dalamnya. Tetapi di era modern saat ini ritual semacam itu sudah banyak ditinggalkan orang. Orang Jawa sendiri semakin menjauh bahkan tidak mengenal ritual semacam itu. Ironisnya ritual semacam itu dianggap sebagai tindakan yang menyesatkan. Padahal realitanya banyak ajaran kebaikan serta nilai-nilai keluhuran yang ada. Akibatnya orang Jawa semakin kehilangan jati dirinya sebagai manusia Jawa. Nilai-nilai luhur manusia Jawa semakin luntur dan banyak orang Jawa yang kehilangan identitasnya, Wong Jawa Ilang Jawane.

Melihat realita yang terjadi terkait nilai-nilai luhur Jawa yang mulai luntur, didukung pengalaman empiris, serta proses refleksi diri memunculkan suatu energi untuk mengangkat persoalan tersebut dalam sebuah karya tari agar manusia Jawa kembali menjadi Jawa. Situs Watu Gilang sebagai tempat yang dijadikan sebagai titik awal penelitian artistik dalam penciptaan karya ini. Hasil riset di lapangan, informasi dari berbagai sumber, serta referensi dari literasi yang ditemukan dijadikan sebagai kekuatan karya Bali Jawi. Gagasan ditransformasikan ke dalam simbol-simbol ketubuhan, musik, properti, serta elemen pendukung lainnya. Simbol-simbol yang dihadirkan diharapkan mampu menginspirasi dalam upaya menghidupkan kembali nilai-nilai luhur manusia Jawa. Pencipta tari mencoba melihat kembali masa lalu yang dikaitkan dengan masa kini, sebagai bekal untuk membaca dan melihat masa depan. Nilai-nilai luhur manusia Jawa kembali para ranahnya, dan menjadi gerbang awal menuju kejayaan Nuswantara.

Kata kunci: Bali Jawi, sowan leluhur, nilai-nilai luhur Jawa 


\begin{abstract}
The dance Bali Jawi is inspired by a ritual from the Javanese culture that used to called sowan leluhur; it is a ritual where people do an ancestral pilgrimage. This ritual is often done by a Javanese spiritual person or in Javanese culture called kejawen. The ancestral pilgrimage, sowan leluhur ritual is believed as a Nuswantara heritage. The Javanese spiritual person believes that their ancestors are always njampangi; a term in Javanese means 'keep watching from a distance' their posterity. So, this ritual is often believed as a devotional form to the ancestors. One of the site that often be visited for this ritual is Watu Gilang at Kotagede that was the throne of a king of Mataram Kingdom. There are a lot of honorable values of Java in this ritual. In the other hand, this kind of ritual has been forgotten in this modern era. Javanese people tend to make a distance from this kind of ritual. Ironically, they also tend to consider this kind of ritual as a misguiding doctrine while the fact is there are so many values of kindness included in it. This reality, ironically, make the Javanese people lost their Javanese identity. The honorable values as a Javanese human faded day by day and most of them get lost; it is called "Wong Jawa Ilang Jawane".

Witnessing this reality that the Javanese honorable values begin to be faded, supported by empirical experiences, and also self-reflection brings out energy to raise this issue into a dance work. The Watu Gilang site is the starting point of the artistic research in this dance work creation. The result of the field research, literature research, and information gathered from various resources are processed to be a power from the dance Bali Jawi. The ideas are transformed into bodily symbols, music, dance properties, and other supporting elements. Every symbol presented on this dance are expected to tell the meaning and core values of the dance itself so Bali Jawi could be a meaningful yet high-quality that has honorable values of Java. The dance work is as well expected to inspire people in order to revive Javanese human honorable values. The choreographer is trying to look back to the past and connect it with the present time, as a provision to understand and forecast the future. The honorable values of Javanese human are back to its realm and become the initial gate into the glory of Nuswantara.
\end{abstract}

Keywords: Bali Jawi, sowan leluhur, the honorable values of Java 


\section{PENDAHULUAN}

Judul karya Bali Jawi memiliki 2 kata, yaitu Bali dan Jawi. Kata bali di sini bukan berarti pulau Bali, melainkan bali merupakan bahasa Jawa yang berarti mulih, dalam bahasa Indonesianya berarti kembali. Jawi diartikan sebagai budi (pikiran, akal, prilaku, tata cara, tata krama) Jawa. Jawa dalam konteks ini tidak hanya diartikan sebagai nama sebuah pulau, tetapi lebih pada nilai-nilai luhur Jawa sebagai sebuah identitas manusia Jawa. Jawi dapat diartikan juga sebagai sarining rasa atau intisari dari rasa. Bali Jawi sebuah karya tari yang diilhami sebuah proses spiritual Jawa yang sering disebut dengan Kejawen. Kejawen sendiri pada hakikatnya adalah suatu tata cara, tata krama dalam kehidupan, baik kepada sesama manusia, alam semesta, maupun Sang Pencipta.

Spitual Jawa identik dengan ritualritual. Di Jawa sendiri hal-hal yang berkaitan dengan ritual tradisi sering dilihat sebelah mata. Pada masa sekarang banyak orang menilai ajaran Kejawen melenceng. Ajaran Kejawen yang identik dengan sesaji serta ritual-ritual dinilai sudah tidak sejalan dengan perkembangan zaman. Bagi orang yang kurang memahami akan mengatakan bahwa sesaji merupakan bentuk persekutuan dengan makhluk halus atau jin dan dianggap tidak sesuai dengan ajaran agama. Penilaian tersebut diperkuat dengan tayangan-tayangan televisi ataupun film mengenai keberadaan dukun yang menggunakan sesaji, keris, ataupun benda lain sebagai media untuk berhubungan dengan makhluk kasat mata. Hal tersebut dengan mudah mempengaruhi orang menjadi antipati dengan ajaran Kejawen. Ritual yang menggunakan sarana dupa atau kemenyan, bunga-bungaan, minyak, benda pusaka dan lain sebagainya sering diidentikan dengan halhal yang sesat. Akibatnya sering terjadi deskriminasi terhadap hal-hal yang berkaitan dengan ritual Jawa (kepercayaan, budaya, dan tradisi Jawa lainnya). Penilaian negatif tersebut berdampak pada hilangnya identitas dan nilai luhur Jawa pada orang Jawa itu sendiri. Tradisi Jawa yang diwariskan para leluhur semakin kurang mendapat perhatian dari sebagian besar masyarakat Jawa itu sendiri. Realita yang terjadi bahwa nilai-nilai budi Jawa yang seharusnya melekat pada kehidupan manusia Jawa sudah mulai tergeser dan tergusur.

Di wilayah Kotagede yang merupakan wilayah bekas kerajaan Mataram pada masa pemerintahan Panembahan Senopati terdapat satu peninggalan kerajaan Mataram yang masih dapat dilihat yaitu watu gilang. Watu gilang merupakan satu petilasan yang dipercaya sebagai singgasana Panembahan 
Senopati. Sama halnya dengan petilasan di tempat-tempat lainnya, watu gilang sering dikunjungi orang atau sekelompok orang yang memiliki maksud dan tujuan tertentu. Salah satu tujuan berkunjung ke sebuah petilasan adalah ritual untuk sowan leluhur. Ritual tersebut biasanya dilakukan oleh orang-orang tertentu, misalnya oleh pelaku spiritual, penghayat kepercayaan, ataupun orang-orang yang memiliki kesadaran pribadi untuk selalu mengingat, menjaga, dan merawat tradisi warisan para leluhur. Masyarakat penganut Kejawen percaya bahwa doa yang didengar Gusti atau Sang Pencipta Jagat ini merupakan berkah dari para leluhur. Mereka meyakini bahwa dengan mengedepankan rasa serta intuisi dapat mendekatkan diri dengan Gusti serta para leluhur. Sowan leluhur esensinya adalah Sembahyang. Sembahyang dipakai untuk istilah semua agama, namun jika dipisahkan kata sembahyang berasal dari kata sembah dan Hyang. Sembah berarti menghormat atau memuliakan, sedangkan Hyang adalah sebutan untuk sesuatu yang bersifat ilahiah atau bisa diartikan sebagai roh leluhur.

Orang yang melakukan ritual sowan leluhur biasanya mengenakan ageman atau busana tradisional (Jawa atau sesuai dengan pakaian adat Nuswantara lainnya) dengan mempersembahkan sajen atau sesaji tertentu yang dilanjutkan dengan meditasi. Ritual sowan leluhur banyak memuat nilai-nilai keluhuran yang akan selalu mengingatkan kita pada asal usul sebagai manusia Jawa yang memiliki tata cara, tata krama, serta tradisi yang secara turun-temurun diwariskan para leluhur Nuswantara. Ritual dalam tradisi Jawa justru dapat dijadikan sebagai modal sosial untuk saling menghargai kehidupan. Kehidupan tersebut bisa berupa harmonisasi antara manusia, alam semesta, dan Sang Pencipta. Kejawen mengajarkan filosofi dan etika tentang bagaimana hidup, dan memberikan dampak positif pada hubungan antar manusia dan manusia dengan alam semesta, sesuai dengan hukum alam yang dititahkan Gusti untuk memberikan rasa damai.

Ritual tradisi orang Jawa yaitu sowan leluhur menjadi inspirasi awal karya Bali Jawi. Riset dan penelitian artistik diawali dari situs watu gilang di Kotagede, Daerah Istimewa Yogyakarta. Ritual sowan leluhur juga dilakukan di situs-situs lain yang berupa Sendang, Goa, Gunung, Candi, Laut, dan sebagainya. Ritual sowan leluhur salah satu wujud penghormatan pada para leluhur yang telah mewariskan penanda peradabannya yang sangat tinggi seperti candi-candi yang membentang indah di penjuru Nuswantara. Sebagai cikal bakal yang ada di tanah Jawa ini sepatutnya dihormati dan dimuliakan. 
Salah satu ungkapan yang sangat popular dalam kehidupan orang Jawa sejak dahulu yaitu wong Jawa nggone semu, sinamun ing samudana, sesadone ingadu manis, yang berarti Orang Jawa menyukai sesuatu yang semu, disamarkan dengan perlambang, diwujudkan dalam keindahan. Sети berarti tersamar atau tidak tampak jelas. Ungkapan ini menunjukkan sifat orang_Jawa yang dalam menyampaikan gagasan kepada orang lain umumnya tidak secara langsung atau tidak secara tegas lugas. Dalam ritual sowan leluhur sering ditemukan dhawuh-dhawuh atau perintah yang berupa sanepan yang harus dikupas maknanya. Sanepan merupakan bentuk komunikasi Jawa dengan memberikan tanda-tanda melalui bahasa kiasan yang memiliki makna-makna tertentu. Hal tersebut yang menginspirasi tercetusnya ide karya Bali Jawi yang menghadirkan simbol-simbol yang terkait dengan kebudayaan Jawa baik masa lampau maupun masa kini.

\section{PEMBAHASAN}

Bali Jawi dalam pertunjukkannya mencoba membawa kita ke masa lalu, kembali ke awal akan nilai nilai kehidupan, kembali kepada kebudayaan Jawa yang sarat akan pemaknaan. Bali Jawi dibuka dengan munculnya simbol yang memiliki karakter kuat akan budaya Jawa yaitu simbol segitiga. Simbol segitiga tersebut dapat diartikan sebagai meru atau gunung, candi, pohon hayat, dan juga menjadi simbol raga, yakni tempat bersemayam sang Atma (ruh) sebagai Hyang Maha Suci. Atma disimbolkan sebuah lingkaran kecil yang berada di dalam segitiga. Simbol segitiga dapat juga sebagai lambang tiga kesatuan yaitu bhurloka (dunia bawah) bhuwarloka (dunia manusia - dunia tengah) dan swarloka (surga - tempat Dewa tinggal dan tempat keabadian). Selain itu, simbol segitiga dapat diartikan sebagai keterhubungan antara manusia-alam semesta-Sang Pencipta.

\section{Latar belakang dari sett property} berbentuk gunung atau segitiga adalah lingkaran yang menggambarkan bumi atau tempat kita berada sebagai mayapada atau dunya (dunia) di mana manusia hidup di dalamnya. Gunung, gunungan, candi dengan bumi yang bersanding saling melengkapi dan diterangi oleh bintang di langit adalah simbol kesatuan yang utuh antara manusia dengan semesta, satu kesatuan antara mandala (lingkaran kehidupan) sebagai gambaran laku manusia dengan Sang Penciptanya dalam bentuk gunung sebagai simbul keabadian. Bali Jawi mengawali pertunjukkannya dengan sebuah pemaknaan akan harapan kembalinya manusia Jawa kepada nilai-nilai luhur kebudayaan Jawa yang sesungguhnya. 


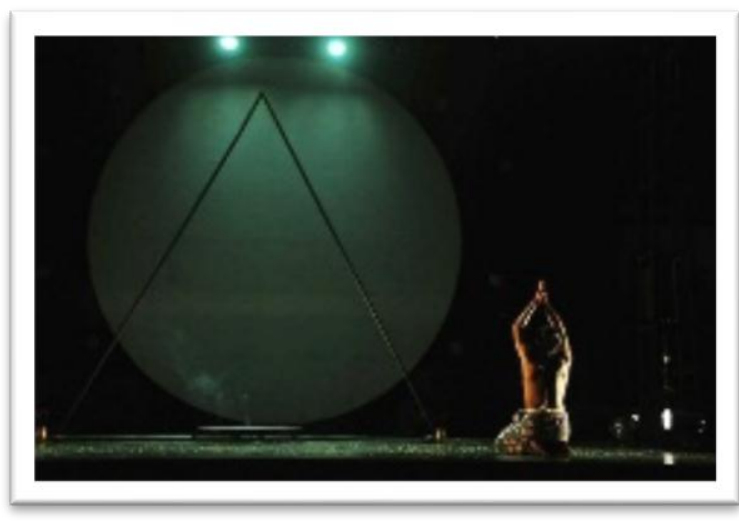

Gambar 1: Simbol segitiga dan lingkaran dalam karya tari Bali Jawi (Dok: Anter Asmorotedjo, 2018)

\section{Bali Jawi yang merupakan sebuah} harapan untuk menghidupkan kembali nilainilai luhur manusia Jawa yang telah pudar. Manusia perlu merefleksikan dirinya agar dapat melihat kembali asal-usulnya sehingga akan menemukan kembali identitasnya. Identitas yang dimaksudkan adalah jatidiri sebagai manusia Jawa yang lahir, hidup, dan akan mati di tanah Jawa. Perlu disadari juga asal-usul para leluhurnya, sehingga anak bangsa ini akan senantiasa percaya diri dan bangga terhadap segala yang diwariskan para leluhur kepada anak cucunya.

Referensi karya didapat secara langsung pada saat terjun di lokasi penelitian, juga dari hasil diskusi dengan beberapa narasumber. Sering ditemukan informasi yang berbeda antara yang didapatkan di satu tempat dengan tempat lainnya, atau informasi yang diperoleh berbeda dengan literasi yang ada.
Bagi pencipta tari perbedaan tersebut dijadikan sebagai referensi yang saling melengkapi.

Karya tari Bali Jawi ini juga merupakan proses refleksi diri terhadap pengalaman hidup yang dialami pencipta tari. Pencipta tari mengalami perubahan cara berpikir dari waktu ke waktu dalam melihat dan memahami sebuah peristiwa terkait dengan ritual Jawa. Pencipta tari menyadari bahwa tidak mudah menetapkan tema karya ini. Pengalaman yang dilihat, didengar dan dirasakan kadangkala tidak bisa dibuktikan. Referensi tidak selalu dapat dijumpai dalam literasi. Namun motivasi muncul karena melihat budaya Jawa dikenal juga dengan sastra tutur atau sastra lisan, sehingga setiap informasi tidak selalu mengacu pada referensi yang tertulis.

Karya tari Bali Jawi berdurasi kurang lebih 35 menit, dengan pembagian adegan yang terstruktur. Struktur adegan dalam karya ini dipisahkan berdasarkan esensi dari nilainilai yang ingin disampaikan. Pembagian adegan dalam karya Bali Jawi terbagi menjadi enam babak sebagai berikut:

\section{A. Bapa Akasa-Ibu Pertiwi}

Seorang perempuan yang mengandung berjalan pelan membawa bokor berisi benih jagung. Jagung diartikan sebagai "penjaga agung" (penjaga tradisi Jawa). Menabur benih 
jagung juga diartikan sebagai menabur benih Jawi atau budi Jawa. Perempuan sebagai simbol Dewi Kehidupan yang menaburkan benih jagung sebagai harapan akan keagungan dan ditanggapi dengan bersinarnya bintang Waluku sebagai bentuk persetujuan alam raya yang tidak pernah menolak semua bentuk kelahiran untuk menyeimbangkan kehidupan fana.

Kehidupan baru akan selalu membawa harapan baru yang seharusnya tak bisa lepas dari kehidupan masa lalu, karena masa lalu akan membentuk saat ini dan menyiapkan ukiran cerita untuk kehidupan nanti. Hadirnya kehidupan baru diharapkan sebagai penjagapenjaga warisan para leluhur yang telah meninggalkan peradabannya yang sangat tinggi.

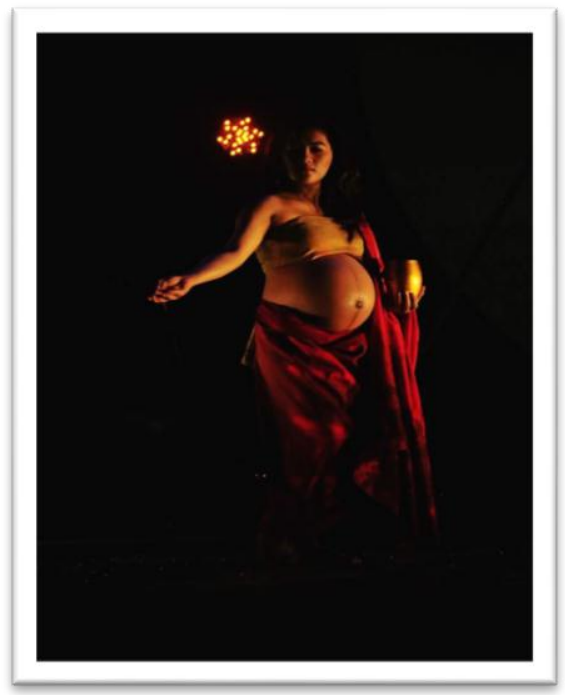

Gambar 2: Sosok perempuan yang mengandung menebarkan benih jagung

(Dok: Anter Asmorotedjo, 2018)
Perempuan sebagai simbol Dewi Kehidupan bisa juga diinterpretasikan sebagai Dewi Sri, Dewi Gangga, atau sebagai penggambaran Ibu Pertiwi. Pada adegan tersebut dimunculkan sosok Garuda. Sosok Garuda mewakili penghuni antariksa atau akasa, sehingga kehadiran dua sosok tersebut dapat dijadikan sebagai penggambaran bapa akasa-ibu pertiwi. Bumi dan langit seringkali disapa sebagai pasangan, hal ini menekankan gagasan akan dua sisi yang saling melengkapi satu sama lainnya.

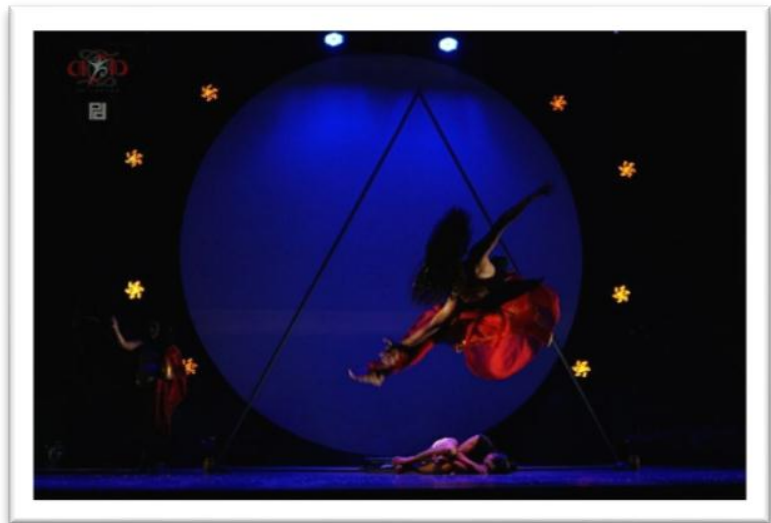

Gambar 3: Penari laki-laki dengan gerakan terbang sebagai penggambaran sosok Garuda. (Dok: Anter Asmorotedjo, 2018)

\section{B. Agama Ageming Aji}

Sosok penari tunggal sebagai penggambaran manusia yang merefleksi perjalanan hidupnya. Manusia tumbuh dewasa bukan hanya berarti fisik, tetapi juga tumbuh akal budinya. Pandangan hidup manusia sering dipengaruhi oleh berbagai hal, misalnya pengaruh dari keluarga, lingkungan, pendidikan, dan lingkungan pergaulan lainnya. Sejak kecil manusia sering dipengaruhi oleh dogma-dogma yang diajarkan dalam keluarga, lingkungan, ataupun pendidikan di sekolah. 
Akibatnya ketika tumbuh dewasa, pikiran manusia sering terbawa dogma yang diterima sejak masa kecilnya. Ketika manusia tumbuh dan mulai bisa berpikir secara jernih, ia akan dapat menentukan pilihannya. Memilih untuk tetap mengikuti dogma yang sudah merasuk atau mencoba lepas dari dogma tersebut. Manusia mengalami proses kedewasaan berpikir seiring dengan hadirnya peristiwaperistiwa yang dialami dalam perjalanan hidupnya.

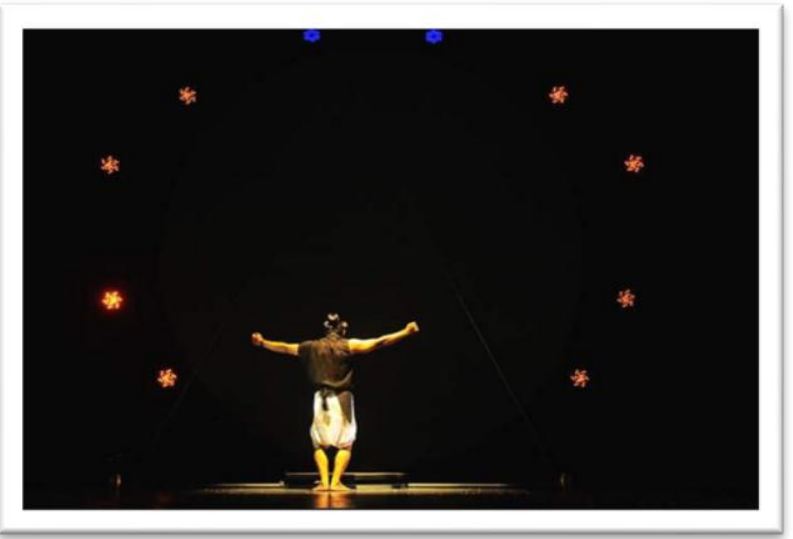

Gambar 4: Adegan seseorang yang sedang merefleksi diri yang kemudian merubah jalan pikiran yang telah terbebas dari dogma.

(Dok: Anter Asmorotedjo, 2018)

Adegan ini sebagai imajinasi sebuah perjalanan manusia yang merefleksi dirinya untuk menemukan identitasnya sebagai manusia Jawa. Didasari oleh kegelisahan melihat kondisi dan realita bahwa banyak orang telah menjauh dari budayanya sendiri. Nilai-nilai luhur mulai ditinggalkan sehingga orang Jawa sendiri mulai kehilangan identitasnya, Wong Jawa Ilang Jawane.
Akhir dari bagian ini, penari mengenakan jarik bermotif aksara Jawa. Kain atau jarik dihadirkan sebagai simbol ageman atau busana. Penghayatan keagamaan orang Jawa tercermin dalam ungkapan agama ageming aji. Dalam konteks ini, agama yang dimaksud adalah kepercayaan Jawa yang merupakan produk nurani yang sudah dianut oleh masyarakat Jawa sebelum agama-agama asing masuk ke Nuswantara. Hidup adalah laku pribadi sehingga harus berjalan mengikuti rasa yang sejati.

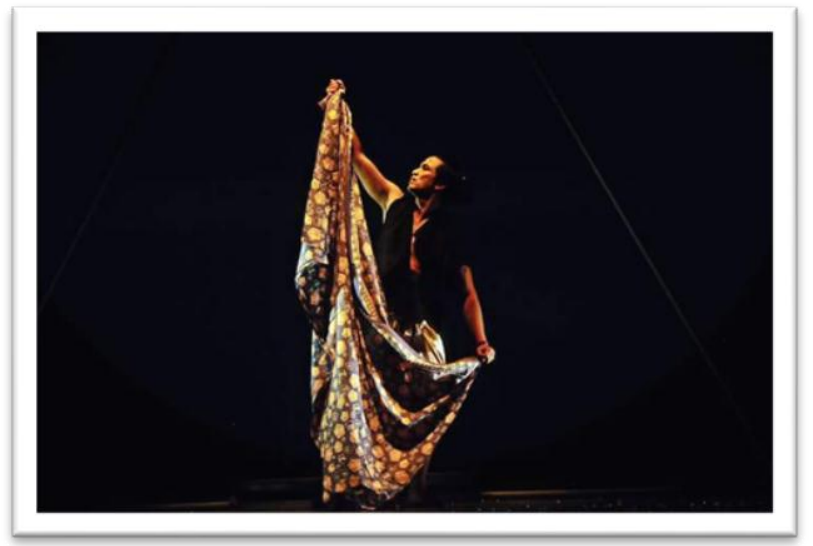

Gambar 5: Gambaran manusia yang memilih jalan hidup yang sesuai dengan rasa yang sejati. (Dok: Anter Asmorotedjo, 2018)

\section{Sang Pamomong}

Spiritual Jawa sangat lekat dengan sosok pamomong. Pamomong dapat diartikan sebagai pengasuh, pembimbing, pengawal, dan sebagainya. Bagian ini dihadirkan dua sosok pamomong yaitu Togog dan Semar. Dalam pewayangan dua sosok tersebut sering disebut dengan punokawan kiri (Togog) dan 
punokawan kanan (Semar). Punakawan atau panakawan diartikan sebagai seorang pengasuh, pembimbing yang memiliki kecerdasan pikir, ketajaman batin, serta kecerdikan akal budi. Wawasannya sangat luas dengan sikap yang bijaksana serta arif dengan segala pengetahuan. Tokoh wayang yang dikenal memiliki sifat punakawan salah satunya adalah Semar. Pada hakikatnya Semar adalah manusia setengah Dewa yang bertugas momong atau mengasuh para ksatria sejati. Para ksatria yang diasuh oleh Semar akan beruntung karena akan menuju kepada nilainilai kebaikan. Togog adalah pendamping kegelapan bagi para ksatria berwatak angkara, tetapi ia menjalankan tugas sebagai sosok pengingat kesadaran akan akibat dari perilaku keburukan yang menjadi sifat dasar para asuhannya.

Togog-Semar merupakan dua sosok yang saling melengkapi. Dalam karya ini kedua sosok tersebut mengenakan kain yang terdiri dari dua warna yaitu hitam dan putih. Togog mengenakan kain motif slobok, dan Semar mengenakan kain motif poleng. Adegan ini juga memunculkan dua penari dalam balutan satu busana berwarna hitam dan putih. Dwi warna tersebut menggambarkan dua sisi kehidupan yang saling terkait dan saling melengkapi. Warna hitam-putih dapat diinterpretasikan sebagai simbol gelap-terang, isi-kosong, malam-siang, berat-ringan, halus- kasar, baik-buruk, dan sebagainya. TogogSemar dapat juga sebagai yin-yang dalam budaya Jawa.

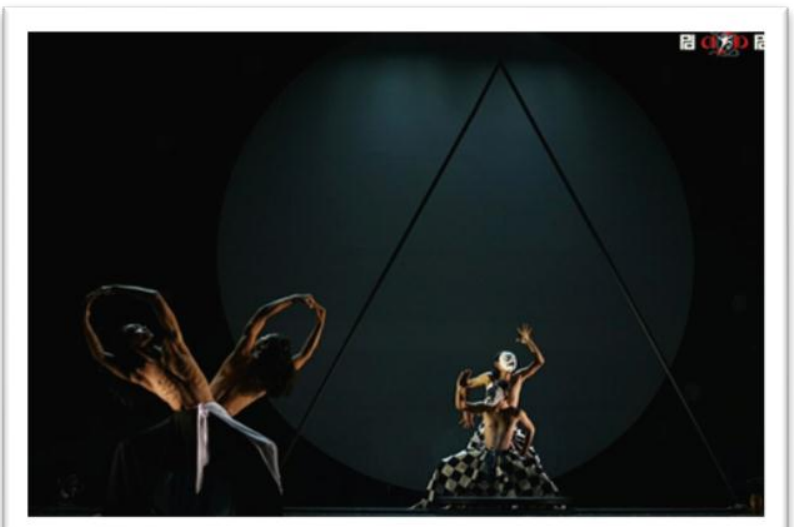

Gambar 6: Dua sosok pamomong Togog-Semar serta dua penari lain sebagai penggambaran dari dua sisi yang saling melengkapi

(Dok: Anter Asmorotedjo, 2018)

Dalam spiritual Jawa, peranan Togog dan Semar berposisi sebagai pamomong para ksatria di muka bumi. Pamomong dipercaya sebagai sosok gaib yang selalu mendampingi dan mengasuh setiap manusia. Pada peradaban yang lain, dua sosok tersebut dipercaya sebagai wujud Sabdo Palon-Naya Genggong. Jangka Sabda Palon yang terserat dalam Serat Darmagandhul berisi tentang kisah kehancuran Jawa dan ajaran-ajaran rahasia. Jawa yang telah berabad-abad telah dihancurkan, diramalkan bakal kembali pada masa kejayaan. Dua pamomong selalu mengawal setiap peradaban tergambar dalam adegan ini. 


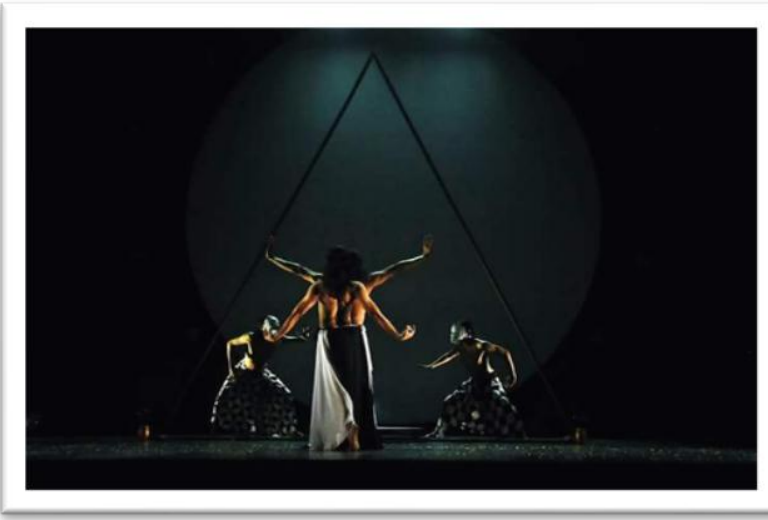

Gambar 7: Dua pamomong sebagai keseimbangan yang selalu melengkapi.

(Dok: Anter Asmorotedjo, 2018)

\section{Mikrokosmos dan Makrokosmos}

Bagian ini muncul sosok manusia menggunakan topeng hewan dan kostum yang terbuat dari tumbuhan. Jenis hewan atau binatang yang dipilih adalah jenis hewan yang sering dijumpai dalam mitos. Hewan mitologi yang dihadirkan antara lain; lembu, harimau, gajah, wanara, garuda, unicorn atau kuda bercula. Bagi yang percaya, hewan-hewan tersebut diyakini ada dan berada di area yang tidak terlihat atau unseen area. Manusia perlu mengakui keberadaan dan eksistensinya. Jenis hewan-hewan tersebut salah satunya dapat dilihat dalam candi-candi di Nuswantara.

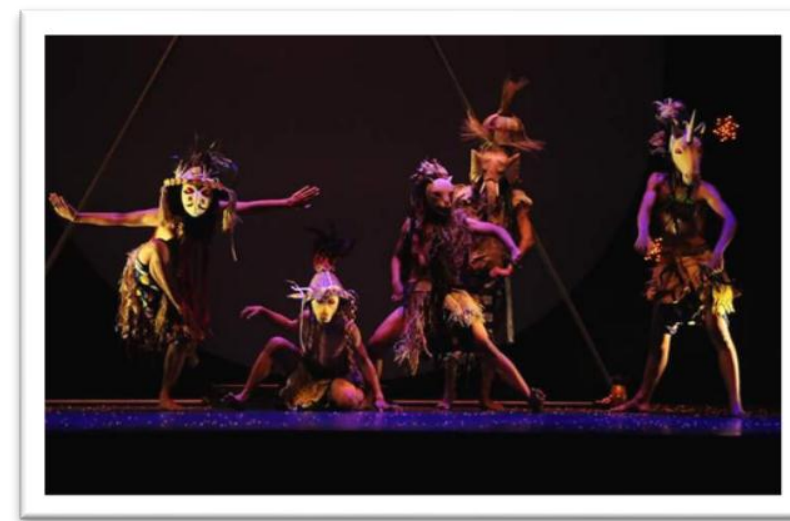

Gambar 8: Berbagai hewan yang terinspirasi pada hewan mitologi, yang sering ditemukan pada candicandi.

(Dok: Anter Asmorotedjo, 2018)

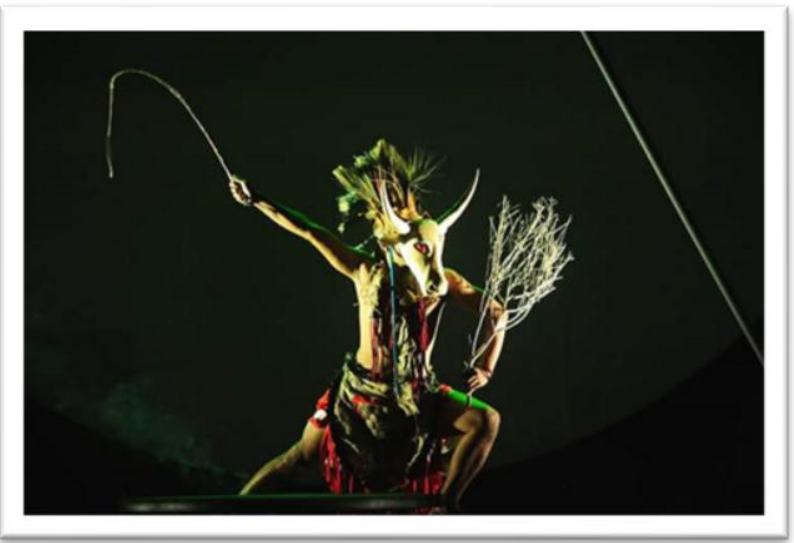

Gambar 9: Sosok sebagai penggambaran sebuah sinergi antara manusia, hewan, dan tumbuhan. (Dok: Anter Asmorotedjo, 2018)

Salah satu ciri etika Jawa ditunjukkan pada tujuan manusia Jawa adalah menjaga keselarasan semesta. Manusia Jawa selalu memperhatikan hubungan kosmis, yaitu hubungan horizontal dan hubungan transendental. Hubungan horizontal yaitu hubungan antara manusia dengan makhluk lain seperti hewan dan tumbuhan atau makhluk mati seperti tanah, air, api, udara, serta lingkungannya. Hubungan transendental adalah hubungan manusia dengan Gusti 
atau Sang Pencipta. Dari sini dapat ditangkap, bahwa masyarakat Jawa sangat mendambakan hubungan dinamis antara manusia-alam-Sang Pencipta. Hubungan ideal antara mikrokosmos (jagad alit) dan makrokosmos (jagad ageng).

\section{E. Eling lan Waspada}

Jiwa ksatria sebenarnya menjadi ciri masyarakat Jawa. Misalnya di Inggris dikenal knight, di Jepang dikenal dengan nama samurai. Hal tersebut menyatakan bahwa menjadi ksatria bukan semata-mata cita-cita masyarakat Jawa. Di Jawa, pembelajaran dan pewarisan jiwa ksatria dapat dilihat melalui pertunjukan wayang. Tokoh Bima dan Arjuna menjadi contoh dua ksatria sejati.

Bagian ini jiwa ksatria tergambar dalam penari kelompok yang menggambarkan masyarakat Jawa yang siap membela tanah leluhur. Mereka adalah gambaran orang-orang yang peduli dan masih menjunjung nilai-nilai keluhuran Jawa yang semakin lama hilang akibat dari masuknya pengaruh-pengaruh asing yang berupaya menggeser dan menggusur paham-paham yang sebelumnya diyakini masyarakat Jawa.

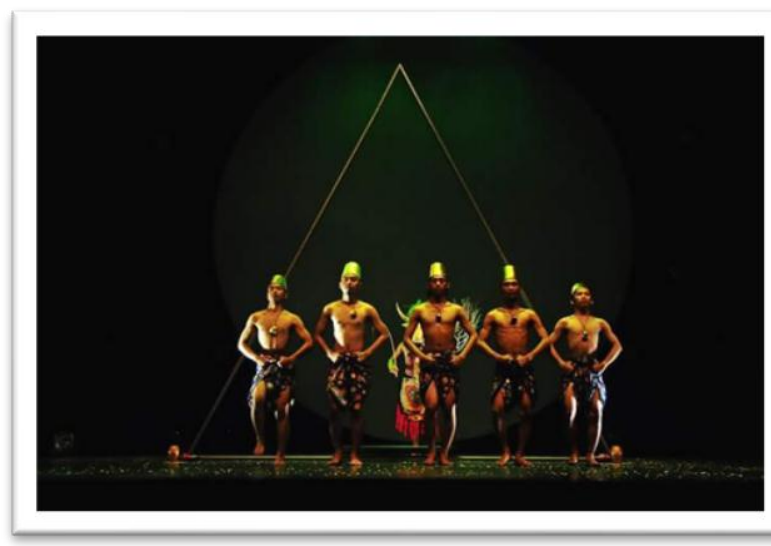

Gambar 10: Penari sebagai lambang seseorang yang memiliki jiwa ksatria.

(Dok: Anter Asmorotedjo, 2018)

Penari mengenakan kuluk warna emas.

Kuluk warna emas sebagai simbol keluhuran yang dipakai di kepala. Di Jawa, kepala merupakan lambang kehormatan manusia, maka keluhuran harus selalu dijunjung tinggi. Adegan ini menggambarkan bahwa masyarakat Jawa pada zaman dulu telah memiliki kepercayaan sendiri sebelum agamaagama asing masuk ke Nuswantara. Kepercayaan yang dianut muncul dari nurani orang Jawa. Masyarakat Jawa juga sangat toleransi terhadap agama-agama yang masuk ke Nuswantara. Tetapi yang terjadi saat ini justru kepercayaan Jawa seolah terasing di negeri sendiri.

Realita yang terjadi bahwa banyak orang Jawa sendiri menjauh dari budayanya. Di era modern ini juga banyak orang terlena akan pengaruh-pengaruh asing yang secara tidak langsung mempengaruhi budaya yang ada. Sebagai contoh adalah orang mudah terhasut oleh iming-iming surga namun lupa 
akan esensi hidup yang harus selalu membawa kedamaian bagi sesama. Bagian ini sebagai pengingat bahwa hidup harus selalu ingat dan waspada. Beja-bejane kang lali, luwih beja kang eling lan waspada, yang artinya seberuntungnya orang yang lupa, akan lebih beruntung orang yang selalu ingat dan waspada.

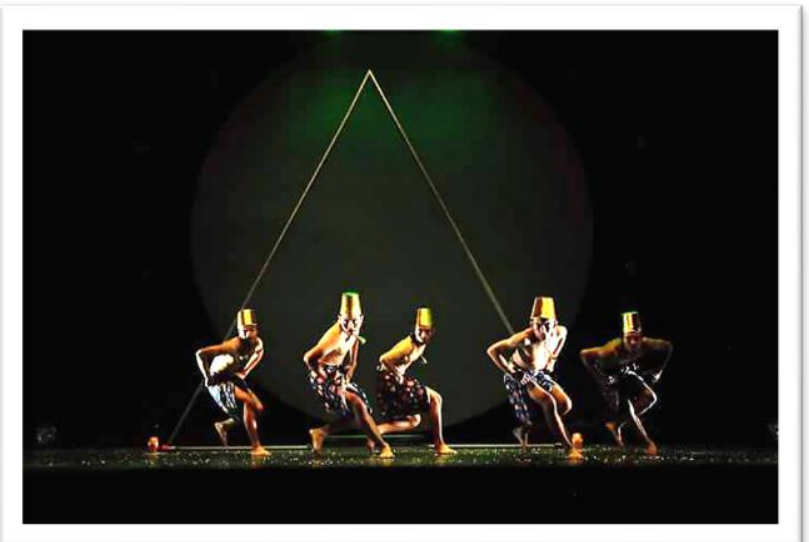

Gambar 11: Penari yang menggambarkan sikap Eling lan waspada, jika tidak hati-hati akan terjerumus pada hal-hal yang merugikan. (Dok: Anter Asmorotedjo, 2018)

\section{F. Memayu Hayuning Bawana}

Meditasi telah dilakukan para leluhur Nuswantara untuk menemukan pembebasan diri dan kesejatian hidup. Meditasi merupakan pencarian ke dalam diri dan merupakan perjalanan panjang yang tidak terbatas. Meditasi sebuah jalan personal yang tidak tergantung pada orang lain.

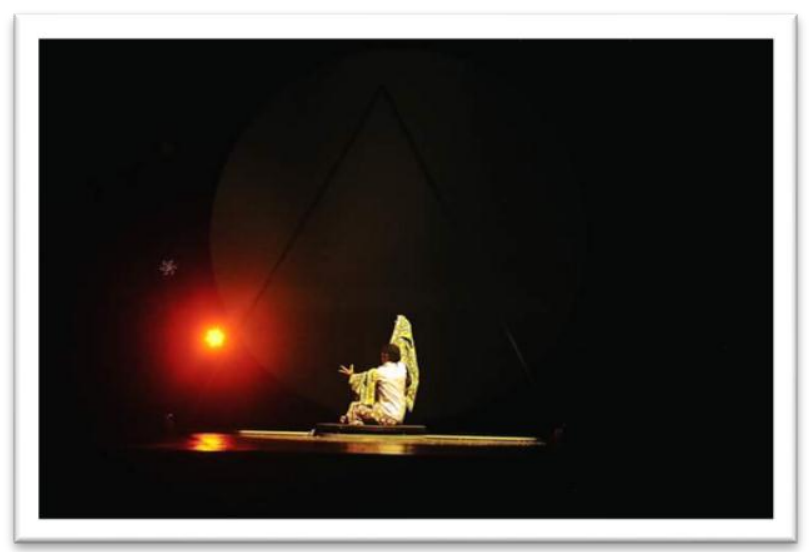

Gambar 12: Penari berada di lingkaran dalam segitiga, manusia mulai menemukan kesejatiannya yang diperoleh melalui laku panjang. (Dok: Anter Asmorotedjo, 2018)

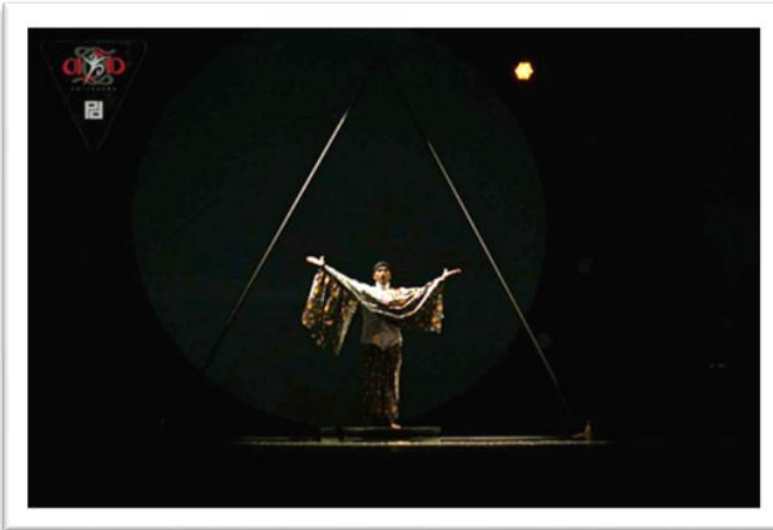

Gambar 13: Menatap dengan penuh percaya diri untuk kehidupan yang selalu hamemayu hayuning bawana.

(Dok: Anter Asmorotedjo, 2018)

Seorang penari berbusana tradisi Jawa berdiri di tengah lingkaran yang jika ditarik garis ke atas persis satu garis dengan sett property segitiga. Berdiri tegak dan percaya diri, menatap ke depan dengan penuh harapan dan keyakinan. Bangga sebagai manusia Jawa yang memiliki tugas Hamemayu Hayuning Bawana. 
Kelahiran yang berarti munculnya sesuatu yang baru, membentuk sebuah pribadi baru dalam bentuk pembelajaran dan ditempa oleh pengalaman, antara hitam dan putihnya kehidupan dalam satu kesatuan waktu, tidak ada yang terpisahkan seperti konsep keterpaduan antara mikrokosmos dan makrokosmos, antara hitam dan putih, dan antara bertumbuh dan berkembang hingga menemukan kesejatian dalam setiap tuntunan kehidupan. Kekalahaan akan selalu ada meski diharapkan ataupun tidak seiring dengan kehidupan yang terus berputar. Demikian juga dalam proses bertumbuh dan berkembang, tidak selamanya proses belajar untuk berkembang mampu mengikuti tuntunan yang ada. Tragisnya malah tidak pernah merasa ada yang menuntun dikarenakan tidak bisa menyatu dengan semesta untuk mengenali simbol-simbol atau penanda semesta yang ada di dunia. Sejatinya semesta selalu penuh dengan simbol dan tanda-tanda yang bisa menuntun untuk mendapatkan kesempurnaan, termasuk di dalamnya segala binatang, tumbuhan, dan bintang di langit.

Manusia akan senantiasa belajar sebagai manusia untuk menuju kesejatiannya sebagai manusia yang serba tidak sempurna sehingga perlu untuk selalu niteni, mengamati, menerjemahkan tanda tanda dari semesta untuk menjadikan dirinya paripurna. Keadaan untuk selalu belajar dan berkembang itu dalam peradaban Jawa selaras dengan rasa. Rasa akan mencapai tingkat mengerti dan memahami bukan semata atas bertambahnya usia, tetapi lebih kepada kerelaan untuk belajar dan mempelajari. Dari apa yang telah dipelajari akan terjadi keseimbangan antara mikrokosmos (jagad alit) dengan jagad ageng (makrokosmos) guna menjadikan manusia yang utuh dalam olah rasa maupun dengan semesta. Keseimbangan atau harmoni dengan semesta adalah segalanya bagi manusia Jawa. Sayangnya harmoni ini tak lagi bisa dicapai karena kesadaran untuk oleh rasa bagi manusia Jawa sudah lama ditinggalkan dan dilupakan. Hal ini yang menjadikan Bali Jawi begitu bermakna.

\section{PENUTUP}

Tari merupakan bentuk ungkapan ekspresi dan perasaan secara jujur dari koreografer terhadap peristiwa dan fenomenafenomena yang terjadi di sekitarnya. Ide atau gagasan dituangkan ke dalam gerak, musik, busana, sett properti, serta elemen pendukung lainnya. Karya ini dicoba untuk tidak berhenti pada persoalan garap teknik dan bentuk saja, namun memperkuat isi dan suasananya yang dapat menembus kedalaman rasa. Segala elemen pertunjukan yang dihadirkan difungsikan sebagai media untuk menyampaikan makna yang didasari sebuah 
penelitian artistik. Karya Bali Jawi diharapkan mampu menjadi karya seni yang memiliki bobot dan nilai edukasi sehingga memiliki nilai manfaat bagi orang banyak. Seni pertunjukan ini diharapkan dapat menginspirasi dan memotivasi untuk membangkitkan rasa dan keinginan seseorang (sebagai orang Jawa) untuk menumbuhkan kembali spirit Jawa yang mengandung nilainilai luhur.

Bali Jawi adalah sebuah renungan dari refleksi dan introspeksi diri untuk mencoba mengembalikan kesadaran diri terhadap identitas sendiri (tanah air, tradisi, budaya, sejarah, leluhur, dan sebagainya). Sudah lama nilai-nilai luhur manusia Jawa ini berusaha digeser dan digusur. Ungkapan "Salah satu cara menghancurkan sebuah bangsa adalah manusia dijauhkan dari leluhur dan budayanya". Hal tersebut membuka mata, pikiran, dan perasaan pencipta tari untuk merespons dalam sebuah karya seni. Akhirnya tertuanglah karya tari Bali Jawi, dengan harapan menghidupkan kembali nilai-nilai luhur manusia Jawa. Melalui karya tari Bali Jawi ini pencipta tari ingin berbagi gagasan dari pengalaman yang didapatkan sebagai bahan untuk saling belajar tentang kehidupan. Sesuatu hal yang harus dimulai dari dirisendiri dengan harapan akan memotivasi untuk mengawali tujuan yang lebih besar yaitu nilainilai keluhuran kembali pada diri manusia
Jawa sebagai titik awal menuju pintu gerbang kembalinya kejayaan Nuswantara seperti yang terserat dalam sabda leluhur.

\section{DAFTAR SUMBER ACUAN}

\section{A. Sumber Tertulis}

Achmad, Sri Wintala, Asal-usul \& Sejarah Orang Jawa, Yogyakarta, Araska, 2017. , Etika Jawa, Yogyakarta, Araska, 2018.

Citraninda Noerhadi, Inda, Busana Jawa Kuna, Depok: Komunitas Bambu, 2012.

CR, Otto Sukatno, Nalar Serta Rasionalitas Mistik Dan Ilmu Gaib, Yogyakarta, Pustaka Pelajar, 2016.

Dewantara, Setyo Hajar, Suwung, Ajaran Rahasia Leluhur Jawa, Tangerang Selatan, Kaurama Buana Antara, 2017.

Endraswara, Suwardi, Agama Jawa, Yogyakarta, Narasi, 2015. Memayu Hayuning

Bawana, Yogyakarta, Narasi, 2013.

Farela, Aristo, A Short History Of Java, Surabaya, Ecosystem Publishing.

Guntur, Metode Penelitian Artistik, Surakarta: ISI Press, 2016.

Indrahartanto, Reinkarnasi,Yogyakarta, Narasi, 2008.

Jatmiko, Adityo, Tafsir Ajaran Serat Wedhatama, Yogyakarta, Pura Pustaka, 2012.

Joseph Stockdale, John, Eksotisme Jawa: Ragam Kehidupan dan Kebudayaan Masyarakat Jawa, Yogyakarta: Progresif Book, 2010. 
Kresna, Ardian, Semar \& Togog: Yin Yang Dalam Budaya Jawa, Yogyakarta, Narasi, 2010.

\section{Punakawan: Simbol}

Kerendah Hati Orang Jawa, Yogyakarta, Narasi, 2012.

Maladi Irianto, Agus, Interaksionisme Simbolik: Pendekatan Antropologis Merespons Fenomena Keseharian, Semarang: Gigih Pustaka Mandiri, 2015.

MC, Wahyana Giri, Sajen \& Ritual Orang Jawa, Yogyakarta, Narasi, 2010.

Miroto, Martinus, Karya Cipta Seni Pertunjukan, Riset Artistik-Koreografi Lingkungan Akademis, Yogyakarta: JB Publisher, 2017.

Musman, Asti, Agama Ageming Aji, Menelisik Akar Spiritualisme Jawa, Yogyakarta, Pustaka Jawi, 2017.

P.H, Rahadhian, Eksistensi Candi: Sebagai Karya Agung Arsitektur Indonesia Di Asia Tenggara, Yogyakarta, P.T Kanisius, 2018.

Sandika, I Ketut, Tantra: Ilmu Kuno Nusantara, Javanica, Banten, 2019.

Santosa, Iman Budhi, Manusia Jawa Mencari Kebeningan Hati, Yogyakarta, Diandra Pustaka Indonesia, 2013.

Situngkir, Hokky, Kode-kode Nusantara, Jakarta, Expose, 2016.

Soebachman, Agustina, Hikayat Bumi Jawa, Yogyakarta, Syura Media Utama, 2015.

Suhardi, Manekung Di Puncak Gunung, Yogyakarta, Gajah Mada University Press, 2018.

Sumaryono, Antropologi Tari Dalam Perspektif Indonesia, Yogyakarta: Media Kreativa, 2016.

Tunggono, Victoria, Candi Nuswantara, Jakarta, PB Kompas, 2018.
Yuwana, Prapto, Sang Pamomong: Menghidupkan Kembali Nilai-Nilai Luhur Manusia Jawa, Yogyakarta, Adiwacana, 2012. 